\title{
Extraction of Sulphated Polysaccharides (SPs) from Different Species of Marine Macroalgae and Studying their Role as Natural Anticoagulant
}

\author{
_W. S. Abou El- Kheir ${ }^{1}$, A. H. Farag ${ }^{1}$, F.A. Mourad ${ }^{2}$, Nedal, M. Nasef ${ }^{3}$ and F. \\ Abdelbaset ${ }^{*}$ \\ 1 Botany Department, Faculty of Women for Arts, Science and Education, Ain Shams University, \\ Cairo, Egypt \\ 2 Marine environment, The National Institute of Oceanography and Fisherie, Suez, Egypt. \\ 3 Medical Microbiology and Immunology, Faculty of Medicine, Mansoura University, Egypt.
}

\begin{abstract}
:
Marine algae are the most important source of non-animal sulphated polysaccharides which possess important pharmacological activities such as anticoagulant, antioxidant, anti-inflammatory, antiviral, antibacterial agents. Therefore, marine algae derived sulphated polysaccharides have great potential to be further developed as medicinal products. Marine macroalgae were collected seasonally for one year (September 2013 to August 2014) from the intertidal zone of site I: Ras El-Adabiya which located on the western shore of Suez Bay and site II: Ras Sedr which located north-east of the Gulf of_Suez. The purpose of this study was to extract sulphated polysaccharides from marine macroalgae (Ulva lactuca, Codium dwarkense, Hypnea cornuta, Hormophysa triquetra, Sargassum denticulatum and Cystoseira myrica) by two different methods (hot and cold water extracts) and chemical analysis also done ( protein content, total sugar, sulphate content, sulfer and nitrogen and uronic acid ). The results of the physico-chemical parameters for sea water samples showed that temp ranged between $15-30{ }^{\circ} \mathrm{C}$, $\mathrm{pH} 7.8-8.7$, salinity $38-42$ \%o, DO 6-7 $\mathrm{mg} / \mathrm{L}, \mathrm{NO}_{3} 0.021-4.6 \mathrm{mg} / \mathrm{L}, \mathrm{NO}_{2} 0.004-0.032 \mathrm{mg} / \mathrm{L}, \mathrm{NH}_{4} 0.019-0.3 \mathrm{mg} / \mathrm{L}$ and $\mathrm{PO}_{4}$ $0.005-0.015 \mathrm{mg} / \mathrm{L}$. The potential of use sulphated polysaccharides as natural anticoagulant was tested by the activated partial thromboplastin time (APTT) and the prothrombin time (PT) tests. The results showed that higher blood anticoagulant activity of SPs is proportional to the carbohydrate and sulphate contents and inversely proportional to the protein and uronic acid contents. So, The significant highest value of prothrombin time was $\mathbf{2 6 . 5 0 \pm 0 . 1 0} \mathrm{sec}$ at conc. of $20 \%$ SPs cold extract from the brown alga Hormophysa triquetra, while the lowest value was $\mathbf{1 . 1 3} \pm \mathbf{0 . 0 6} \mathrm{sec}$ at conc. of 5\% SPs hot extract of the red alga Hypnea cornuta. Also, the results indicated that the highest value of activated partial thromboplastin time $\mathbf{4 2 . 2 0 \pm 0 . 1 0} \mathrm{sec}$ was recorded at conc. of $20 \%$ SPs cold extract from the brown alga Hormophysa triquetra, On the other hand, the lowest value $\mathbf{5 . 6 3 \pm 0 . 2 5 ~ s e c ~ w a s ~ r e c o r d e d ~ a t ~ c o n c . ~ o f ~}$ 5\% SPs hot extract from the red alga Hypnea cornuta.
\end{abstract}

Keywords: Ras sedr, Ras El-adabiya, Marine Macroalgae, Sulphated polysaccharides , blood anticoagulation activity.

\footnotetext{
*Corresponding author: Fatma abdelbaset e-mail: Battotnour@yahoo.com
} 


\section{Introduction and Review of Literature:}

Marine algae are ecologically important and have been used as food and medicines for centuries. Different species of marine algae provide not only food but also produce extracts are used in numerous food, dairy, pharmaceutical, cosmetic, and industrial applications (Raja et al.,2013).

Marine algae are considered as valuable sources of structurally diverse bioactive compounds.Sulfated polysaccharides (SPs) in marine algae such as carrageenans in red algae, fucoidans in brown algae and ulvans in green algae exhibit many health beneficial nutraceutical effects such as antioxidant, anti-allergic, anti-human immunodeficiency virus, anticancer, antibacterial and anticoagulant activities. Therefore, marine algae derived SPs have great potential to be further developed as medicinal food products or nutraceuticals in the food industry (Ngo and Kim , 2013).).

Ulvan is the major water-soluble polysaccharide found in green seaweed of the order Ulvales (Ulva spp. and Enteromorpha spp.) that has sulfate, rhamnose, xylose, iduronic and glucuronic acids as main constituents (Lahaye and Ray ,1996) .

Costa et al.(2011) obtained five sulfated heterofucans from Sargassum filipendula by proteolytic digestion followed by sequential acetone precipitation, which displayed considerable antioxidant potential.

The most widely studied bioactivity of marine sulfated polysaccharides is the heparin-like anticoagulant. The blood coagulation system consists of intrinsic and extrinisic pathways, where a series of factors involve in the mechanism. Blood coagulation is proceeded by coagulation factors in order to stop the flow of blood though the injured vessel wall whenever, an abnormal vascular condition and exposure to non-endothelial surfaces at sites of vascular injury occurred. As endogenous or exogenous anticoagulants interfered with the coagulation factors by inactivate or restrict, the blood coagulation can be prolonged or stopped (Jung et al.,2001).

Patel (2012) reported that batteries of assays for assessment of anticoagulation properties of SPs from seaweeds have been conducted in recent times. Tests ranging from activated partial thromboplastin time (APTT), thrombin time (TT) and prothrombin time (PT).

Cold water extracts of all Codium species contain higher sugar and sulphate contents and lower protein and uronic acid contents. Also, cold water extracts exhibited higher blood anticoagulant activity than that of hot water extract. In Udotea spp. hot water extracts showed relatively higher blood anticoagulant activity which contained higher sugar and sulphate contents and lower protein and uronic acid contents. Hence, it can be inferred that higher blood anticoagulant activity is associated with relatively higher contents of sugar and sulphate and lower protein and uronic acid contents (Shanmugam et al., 2002).

The anticoagulant activity of SPs has been identified from several brown algae such as Padina gymnospora (Silva et al.,2005), Dictyota menstrualis (Albuquerque et al.,2004) and Sargassum stenophyllum (Duarte et al., 2001). Also, SPs from green algae such as Monostroma nitidum were potent thrombin inhibitors (Mao et al.,2008). Moreover, Pushpamali et al.(2008) isolated a highly sulfated (21.76\%) anticoagulant from fermented red seaweed Lomentaria catenata. 
Mao et al (2006) mentioned a sulfated polysaccharide from Ulva conglobata with high rhamnose content and 35\% sulfate ester that prolonged clotting time through what appeared to be direct inhibition of thrombin .

The hot water extract of green alga Monostroma latissimum gives a sulfated rhamnan polysaccharide with an anticoagulant activity. The anticoagulant activity as evaluated by assays of the APTT and thrombin time promises that it can be a potential source of anticoagulant (Li et al. 2011).

It was observed that anticoagulant activity was higher in SPs samples with higher sulfate content. In this regard, Codium vermilara proved to be superior with a higher degree of sulfation and arabinose content (Ciancia et al. 2007).

In the prothrombin time (PT) test, which evaluates the extrinsic coagulation pathway, Caulerpa cupresoides showed aggression. Codium fragile and Codium vermilara water-soluble sulfated arabinogalactans prevented coagulation (Ciancia $\boldsymbol{e t}$ al. 2007).

Hayakawa et al. (2000) tested sulfated polysaccharides from 23 green algae species for anticoagulant activity and discovered a high rhamnose-containing sulfated polysaccharide from Monostroma nitidum, the purified version of which was more potent than standard heparin

Pereira et al. (2002) reported that heparin has been identified and used for more than fifty years as commercial anticoagulant and it is widely used for prevention venous thromboembolic disorders. However, several side effects of heparin have been reported such as development of thrombocytopenia, hemorrhagic effect, and ineffectiveness in congenital or acquired antithrombin deficiencies and incapacity to inhibit thrombin bound to fibrin.

Therefore, six marine macro algae were selected to extract sulphated polysaccharides and emphasize the use of them as natural anticoagulants with high efficiency. This is considered as an attempt to get alternative sources for manufacture of novel and natural anticoagulant drugs.

\section{Materials and Methods:}

The marine macroalgae were collected from the intertidal zone of site I: Ras ElAdabiya which located on the western shore of Suez Bay at latitude, longitude (29.681737, 32.508970) respectively and site II: Ras Sedr which located north-east of the Gulf of Suez at latitude, langitude $(29.622328,32.687970)$ respectively and identified according to Papenfuss (1989) as the following (Ulva lactuca, Codium dwarkense (Naser) (Chlorophyceae), Sargassum denticulatum (Børgesen) , Hormophysa triquetra (Kütizing) and Cystoseira myrica (C.Agardah) (Phaeophyceae) and Hypnea cornuta (Rayss and Dor) (Rhodophyceae), as shown in plate (1).

A- Physico-chemical parameters for sea water samples were done:

1) Temperature

2) Hydrogen - ion concentration $(\mathrm{pH})$ : $\mathrm{pH}$ was measured in situ by a $\mathrm{pH}$ meter. 
3) Dissolved oxygen (DO): DO was determined by Winkler method (Strickled and parson ,1968).

4) Water Salinity : Water salinity was measured in the laboratory using an inductive salinometer (S.C.T. meter) Model 33.

5) Determination of ammonium $\left(\mathrm{NH}_{4}\right)$ and nitrate $\left(\mathrm{NO}_{3}\right)$ : Ammonium and nitrate were determined calorimetrically by using UV/Visible spectrophotometer at wave length 400 and $430 \mathrm{~nm}$ respectively (ASTM, 2002).

6) Determination of nitrite $\left(\mathrm{NO}_{2}\right)$ and phosphate $\left(\mathrm{PO}_{4}\right)$ : Nitrite and phosphate determined colorimetrically by using UV/Visible spectrophotometer at wave length of 430 and $880 \mathrm{~nm}$ respectively (ASTM, 2002).

B- Biological parameters (Photosynthetic pigments):

1) Chlorophyll's calculations: Calculations of chlorophyll (a), (b) and (c) concentrations were measured according to APHA (1995)

2) Carotenoids calculations: The spectrophotometric measurements at 510 and 480 were used to calculate carotenoids according to (Timothy et al.,2013) .

Extraction of sulphated polysaccharides by method of Subash et al.(2010) from six marine algal species .

\section{1) Hot water extract :}

-Algal powders were depigmentated and defatted by methanol in a soxhlet apparatus .

$-100 \mathrm{gm}$ of defatted and depigmentated powder of each algae was extracted with 300 $\mathrm{ml}$ of distilled water (90-95) ${ }^{\circ} \mathrm{C}$ for $3 \mathrm{hr}$.

-The coloured syrup filtered through whatman no. 3 paper.

-Then concentrated to $1 / 4$ th of the original volume .

-Cooled and precipitated with $100 \mathrm{ml}$ of ethanol .

-The precipitate was collected by centrifugation for 30 min then dehydrated with diethyl ether and then dried at $37^{\circ} \mathrm{C}$ until diethyl ether free.

-Add $30 \mathrm{ml}$ ethyl acetate then filter and take the residue.

\section{2) Cold water extract:}

The same procedure without heating but the $100 \mathrm{gm}$ of defatted and depigmentated powder of each algae was soaked with $300 \mathrm{ml}$ of distilled water at $4^{\circ} \mathrm{C}$ over night. The yield of sulphated polysaccharide (SPs) extracts was calculated on the basis of the dry weight of algal sample $(100 \mathrm{gm})$. The $\mathrm{pH}$ of SPs extracts was determined using $\mathrm{pH}$ meter, Orion 210 . 


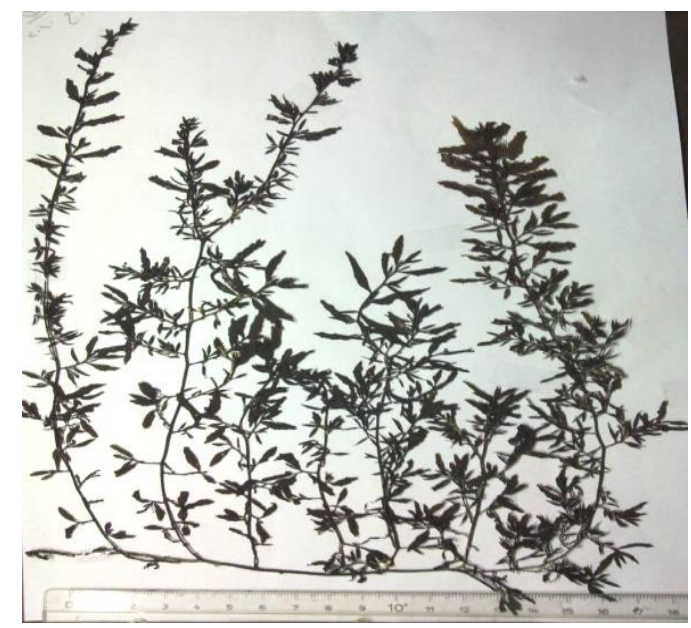

Sargassum denticulatum (BØrgesen)

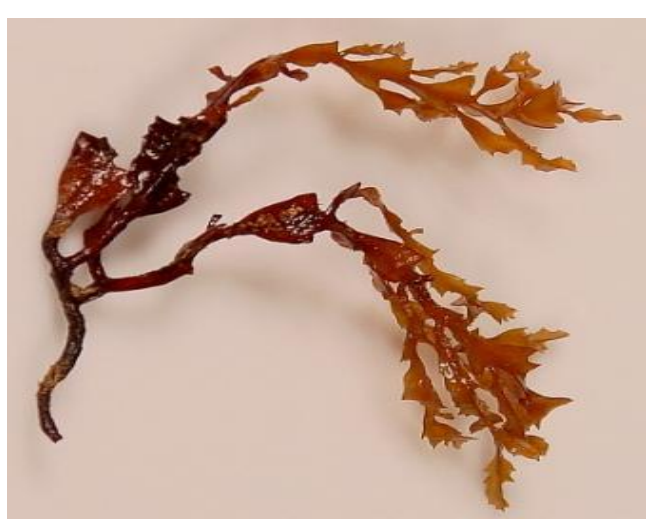

Hormophysa triquetra ( Kütizing)

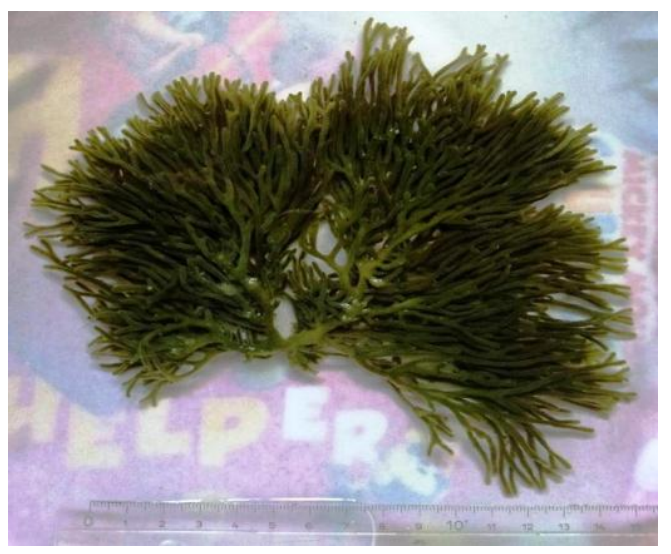

Codium dwarkense (Naser)

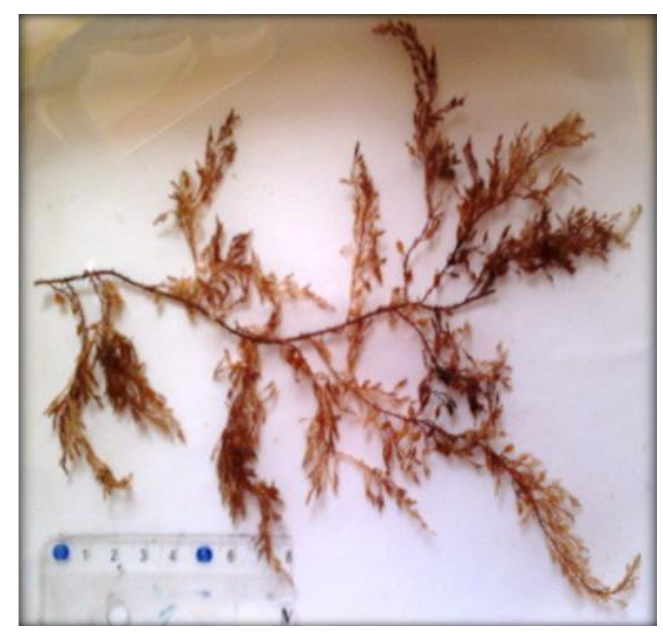

Cystoseira myrica (C.Agardah)

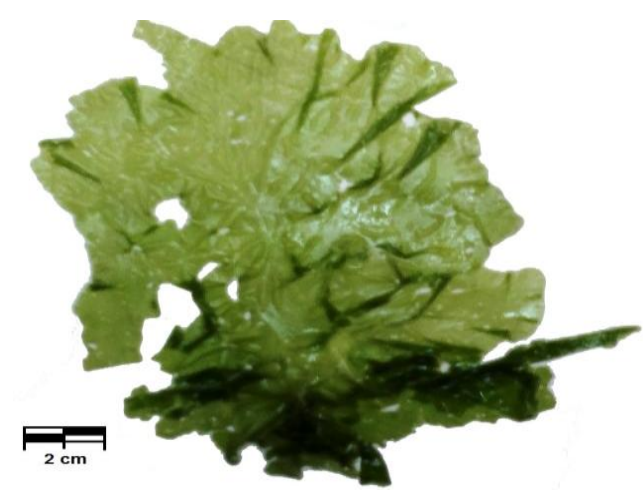

Ulva lactuca

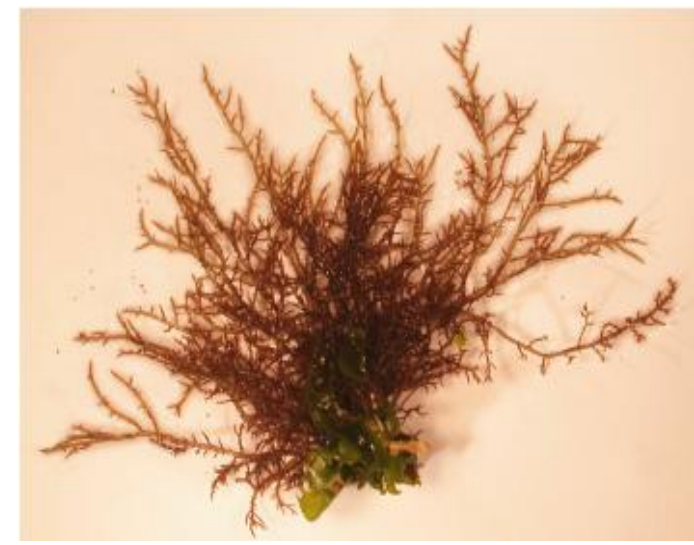

Hypnea cornuta (Rayss and Dor)

Plate (1) 


\section{Analysis of the sulphated polysaccharides extracts :}

1) Protein content: Protein content was measured spectrophotometically using the folin -phenol reagent according to the method described by Lowry et al. (1951) using albumin as a standard .

2) Total sugar: The spectro-photometric method described by Dubois et al.(1956) was used to determine carbohydrates .

3) Sulphate content: Sulphate content of the SPs sample was estimated by hydrolysing the sample with 1.0 N HCL and measured turbidimetrically by $\mathrm{BaCl}_{2}$ gelatin method ( Dodgson and price, 1962).

4) Sulfer and nitrogen analysis: were done on Perkin-Elemer Series II-2400 CHNS/O Analyzer .

5) Uronic acid content: Uronic acid content was determined by the method of Knutson and Jeans (1968).

\section{Blood anticoagulation activity of the sulphated polysaccharides:}

The in vitro anticoagulant activity of the SPs extracts was evaluated by the activated partial thromboplastin (APTT) and prothrombin time (PT) coagulation assays with coagulometer coatron M1.

1) Normal blood plasma was made from individual healthy donor , without history of bleeding or thrombosis with PT $13 \mathrm{sec}$ and APTT $30 \mathrm{sec}$.

2) Algal SPs samples were dissolved in normal saline $(0.85 \%)$ (Shanmugam et al., 2001) and three different concentrations $(5 \%, 10 \%$ and $20 \%)$ from each extract were used for assays. All coagulation assays were performed with three replicates

\section{Results and Discussion}

\subsection{Results}

\section{A-Physico-chemical parameters of sea water samples:}

The seasonal variations of physico-chemical characteristics of sea water samples are (Temp , pH, DO, water Salinity, $\mathrm{NO}_{3}, \mathrm{NO}_{2}, \mathrm{NH}_{3}$ and $\mathrm{PO}_{4}$ ) for Site I: Ras ElAdabiya and Site II: Ras Sedr. The results showed that temp ranged between $15-30{ }^{\circ} \mathrm{C}$ , pH 7.8 - 8.7, salinity 38- 42 \%o, DO 6-7 mg/L, $\mathrm{NO}_{3} 0.021$ - $4.6 \mathrm{mg} / \mathrm{L}, \mathrm{NO}_{2} 0.004$ $0.032 \mathrm{mg} / \mathrm{L}, \mathrm{NH}_{4} 0.019-0.3 \mathrm{mg} / \mathrm{L}$ and $\mathrm{PO}_{4} 0.005-0.015 \mathrm{mg} / \mathrm{L}$.

\section{B-Biological parameter (Photosynthetic pigments):}

\section{1) Chlorophyll (a) content (Fig. 1)}

The highest concentration of chlorophyll (a) was $\mathbf{1 7 . 4 6} \mu \mathrm{g} / \mathrm{L}$ in Codium dwarkense , while the lowest value of $6.9 \mu \mathrm{g} / \mathrm{L}$ in Hypnea cornuta.

\section{2) Chlorophyll (b) content (Fig. 2)}

The highest concentration of chlorophyll (b) was $24.9 \mu \mathrm{g} / \mathrm{L}$ in Ulva lactuca, while the lowest value of $9.1 \mu \mathrm{g} / \mathrm{L}$ in Sargassum denticulatum .

\section{3) Chlorophyll (c) content (Fig. 3)}

The highest concentration of chlorophyll (c) was $12.9 \mu \mathrm{g} / \mathrm{L}$ in Cystoseira myrica , while the lowest value of $\mathbf{1 1 . 3} \mu \mathrm{g} / \mathrm{L}$ in Hormophysa triquetra .

\section{4) Carotenoids content (Fig. 4)}

The highest concentration of carotenoids was $4.65 \mu \mathrm{g} / \mathrm{L}$ in Codium dwarkense , while the lowest value of $\mathbf{3 . 2 6} \mu \mathrm{g} / \mathrm{L}$ in Cystoseira myrica . 


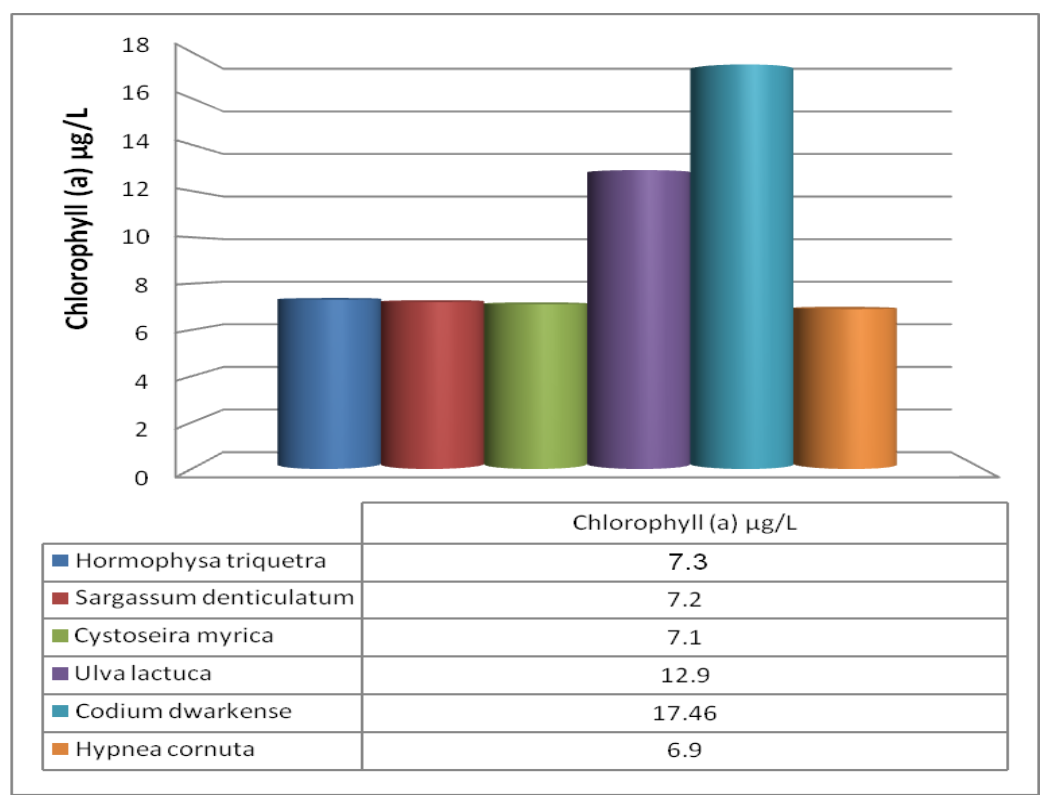

Fig.1: Variation in chlorophyll (a) $(\mu \mathrm{g} / \mathrm{L})$ concentrations in marine algal species .

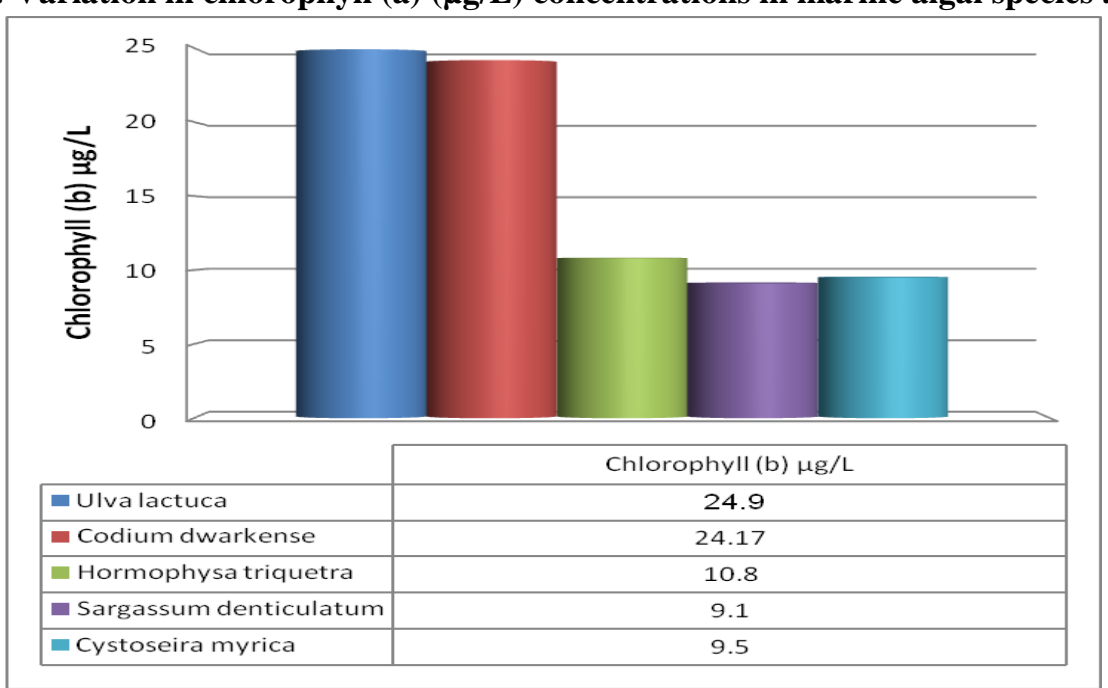

Fig.2: Variation in Chlorophyll (b) concentrations $(\mu \mathrm{g} / \mathrm{L})$ in marine algal species .

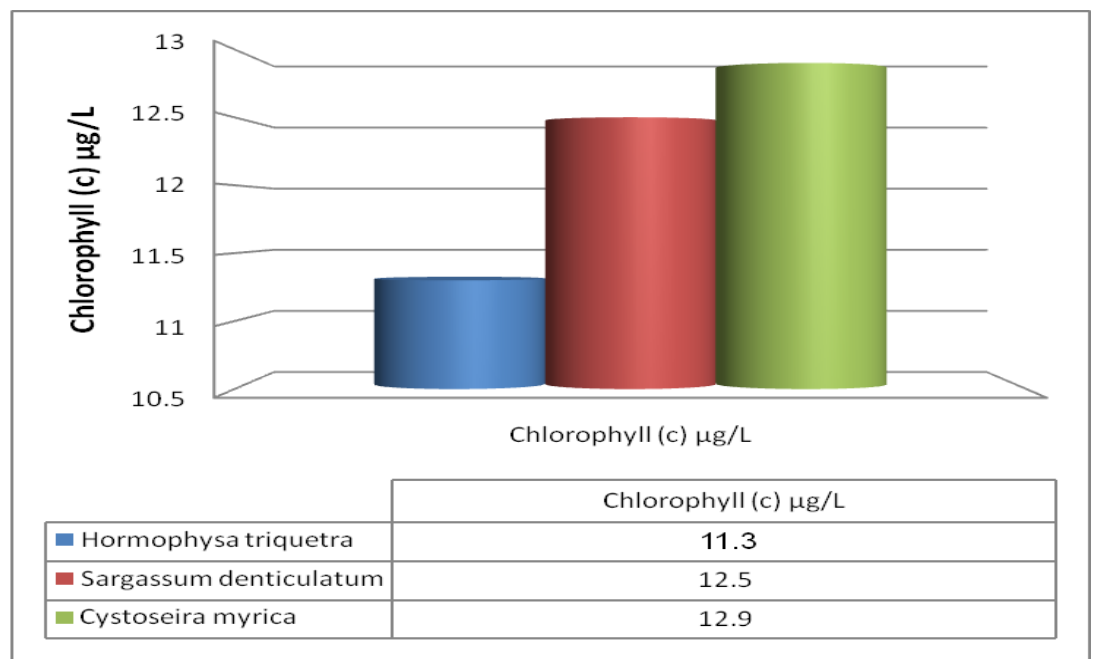

Fig .3: Variation in chlorophyll (c) concentrations $(\mu \mathrm{g} / \mathrm{L})$ in brown marine algal species. 


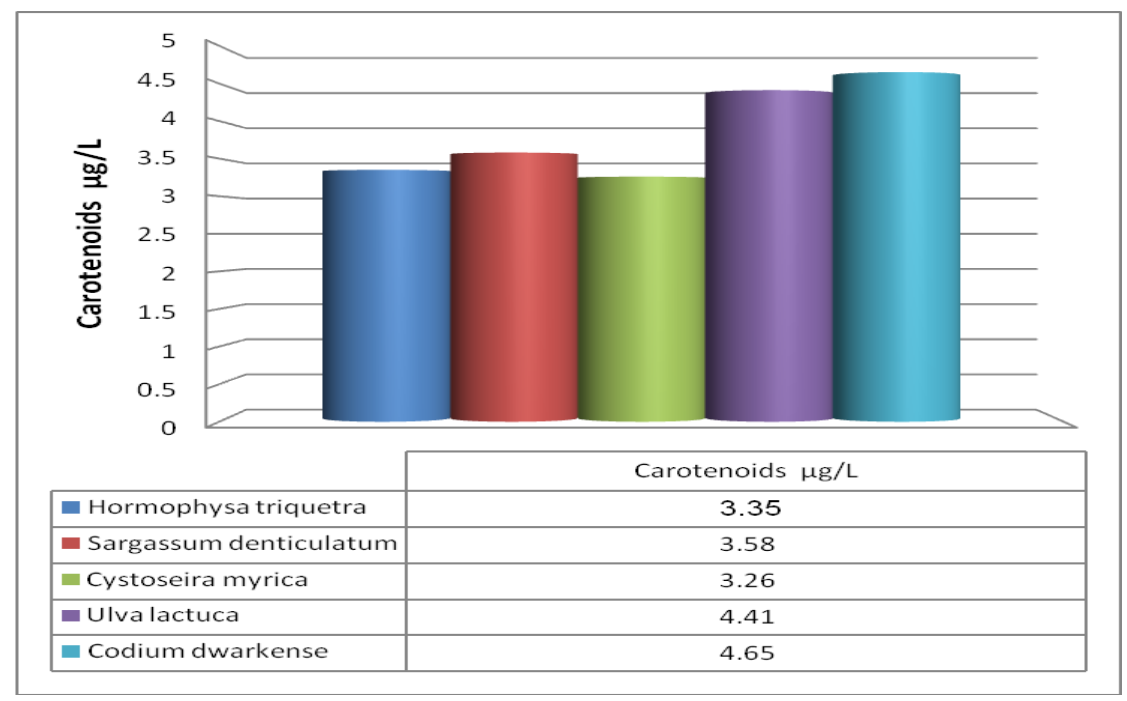

Fig .4: Variation in carotenoids concentrations $(\mu \mathrm{g} / \mathrm{L})$ in marine algal species.

\section{Extraction of Sulphated polysaccharides (SPs) by hot and cold method :}

\section{1)The yield of SPs cold \% (Fig. 5)}

The yield of SPs cold extracts is relatively higher than hot extracts . In cold extracts the highest value was $7 \%$ in Hormophysa triquetra, while the lowest value was $5 \%$ in Hypnea cornuta. On the other hand the maximum value in hot extracts was $6 \%$ in Hormophysa triquetra and the minimum value was $4.3 \%$ in Hypnea cornuta.

\section{2)Chemical properties of Sps:}

\section{- Hydrogen ion concentration pH (Fig. 6)}

$\mathrm{pH}$ values of SPs in cold and hot extracts were always in the alkaline side. . In cold extracts the maximum value was 7.7 in Sargassum dentifolium, while the minimum value was $\mathbf{7 . 1}$ in Ulva lactuca. On the other hand the maximum value in hot extracts was $\mathbf{7 . 9}$ in Hormophysa triquetra and the minimum value was $\mathbf{7 . 2}$ in Codium dwarkense .

\section{- Total sugar \% (Fig.7)}

The cabohydrate concentrations of the SPs cold and hot extracts. In cold extracts the highest concentration value was $\mathbf{5 4 . 2} \%$ in Hormophysa triquetra, while the lowest concentration value was $\mathbf{4 4 . 3} \%$ in Hypnea cornuta. On the other hand the maximum concentration value in hot extracts was $\mathbf{5 3 . 2} \%$ in Hormophysa triquetra and the minimum concentration value was $\mathbf{4 2 . 5} \%$ in Hypnea cornuta .

\section{- Sulphate content \% (Fig.8)}

The sulphate concentrations of the SPs cold and hot extracts. In cold extracts the maximum concentration value was $\mathbf{2 5 . 7} \%$ in Hormophysa triquetra, while the minimum concentration value was $\mathbf{2 0 . 4} \%$ in Hypnea cornuta. On the other hand the maximum concentration value in hot extracts was $\mathbf{2 4 . 4} \%$ in Hormophysa triquetra and the minimum concentration value was $\mathbf{1 9 . 1 \%}$ in Hypnea cornuta . 


\section{- Sulphur content \% (Fig. 9)}

The sulphur concentrations of the SPs cold and hot extracts. In cold extracts the maximum concentration value was $\mathbf{7 . 9 2} \%$ in Hormophysa triquetra, while the minimum concentration value was $\mathbf{5 . 1 1} \%$ in Hypnea cornuta. On the other hand the maximum concentration value in hot extracts was $6.92 \%$ in Hormophysa triquetra and the minimum concentration value was $\mathbf{4 . 6 5 \%}$ in Hypnea cornuta.

\section{- Protein \% (Fig. 10)}

The protein concentrations of the SPs cold and hot extracts. In cold extracts the maximum concentration value was $\mathbf{1 0 . 2 \%}$ in Hypnea cornuta, while the minimum concentration value was $8.4 \%$ in Hormophysa triquetra. On the other hand the maximum concentration value in hot extracts was 8.1\% in Hypnea cornuta and the minimum concentration value was $\mathbf{6 . 3} \%$ in Hormophysa triquetra .

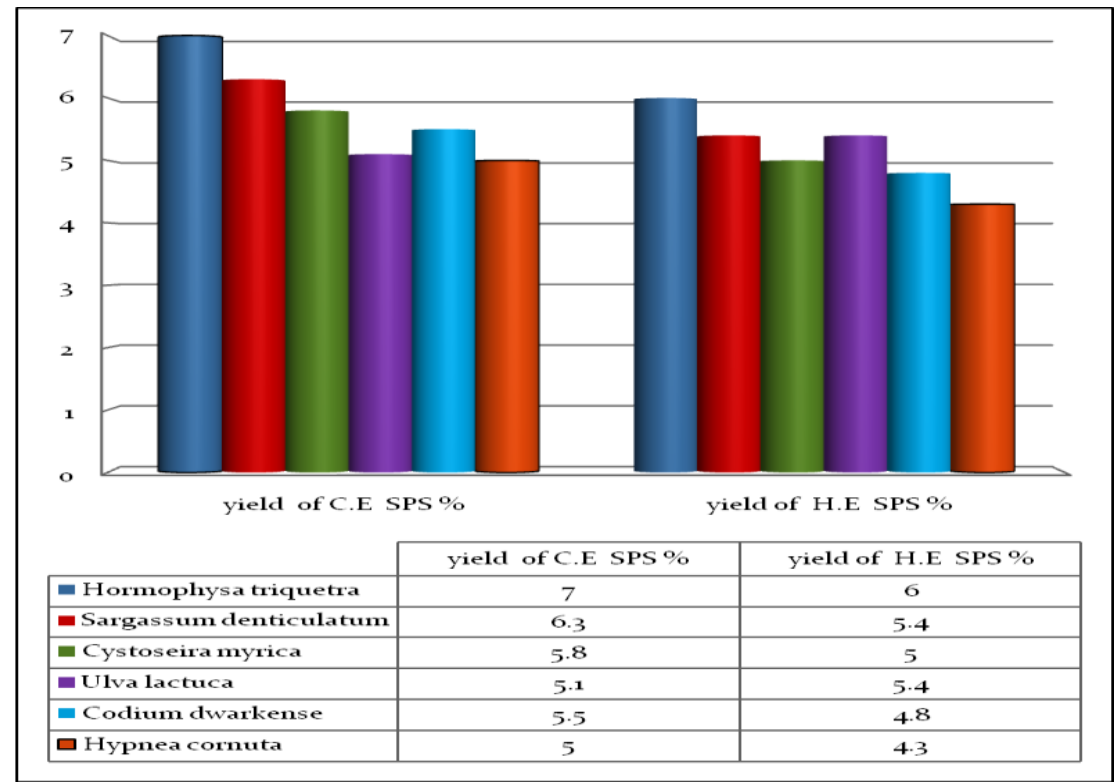

Fig.5: Variations in the yield SPs of cold and hot extracts (\%) for different marine algal species.

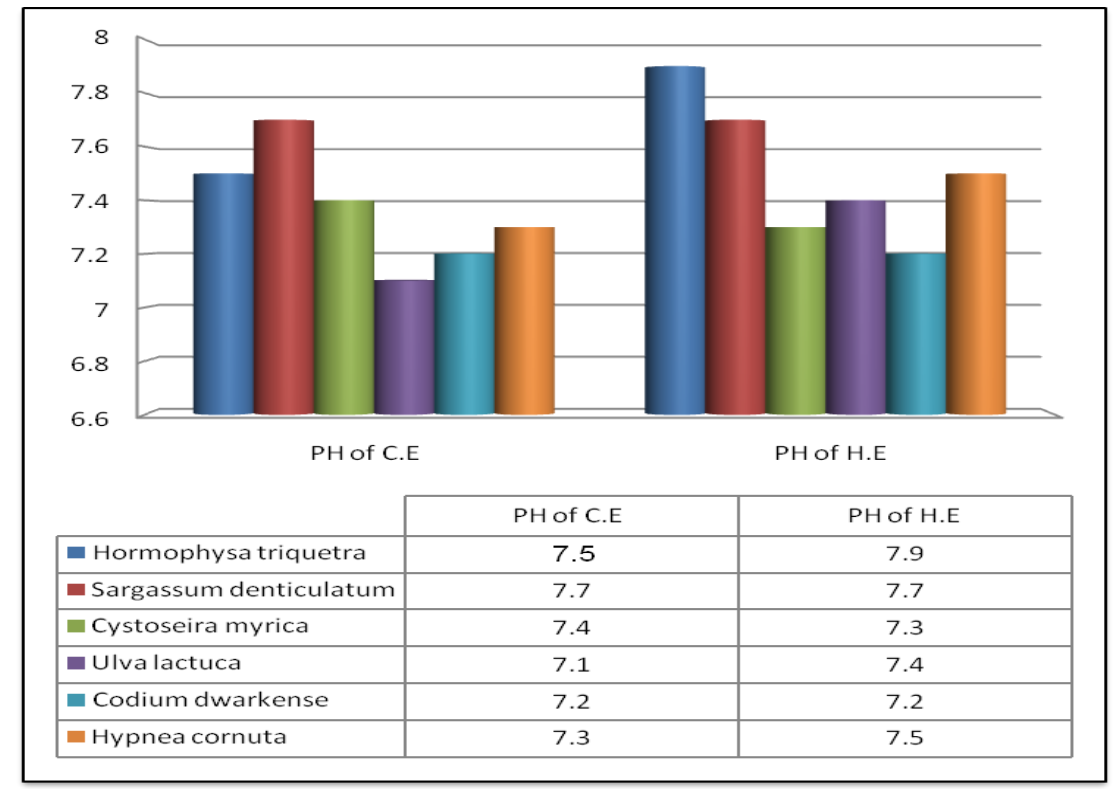

Fig.6: pH variations in the yield SPs of cold and hot extracts for different marine algal species. 


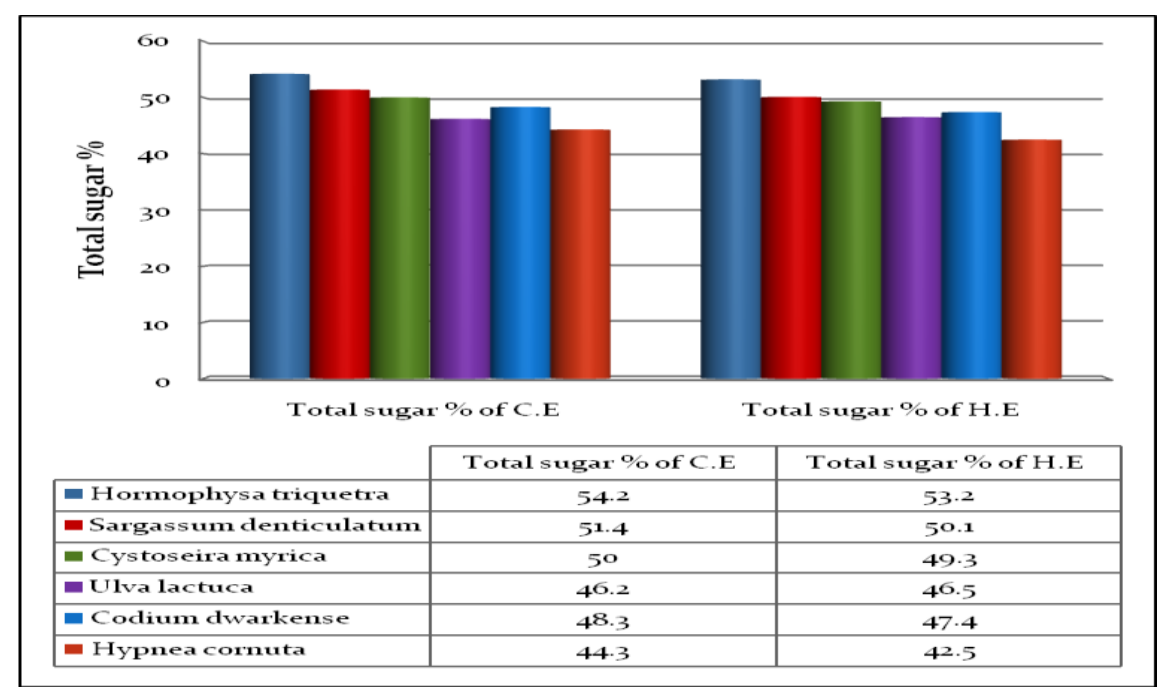

Fig.7: Variations in total sugar content (\%) in the SPs cold and hot extracts for different marine algal species .

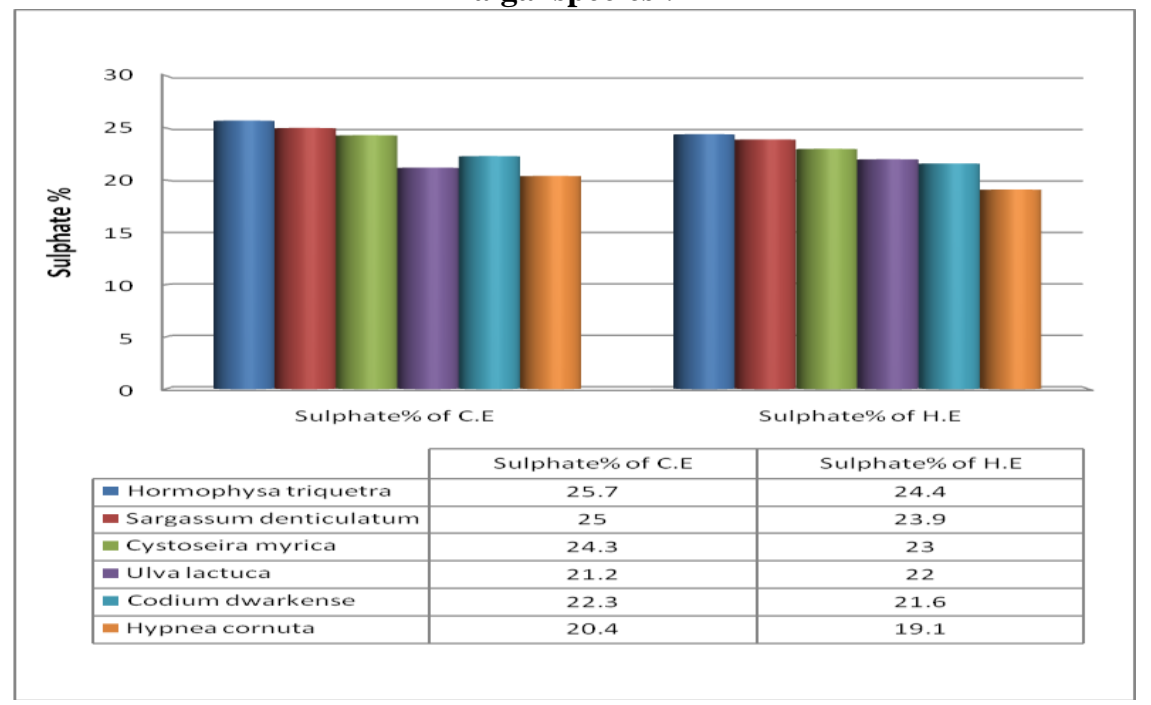

Fig .8: Variations in sulphate content (\%) in the SPs of cold and hot extracts for different marine algal species .

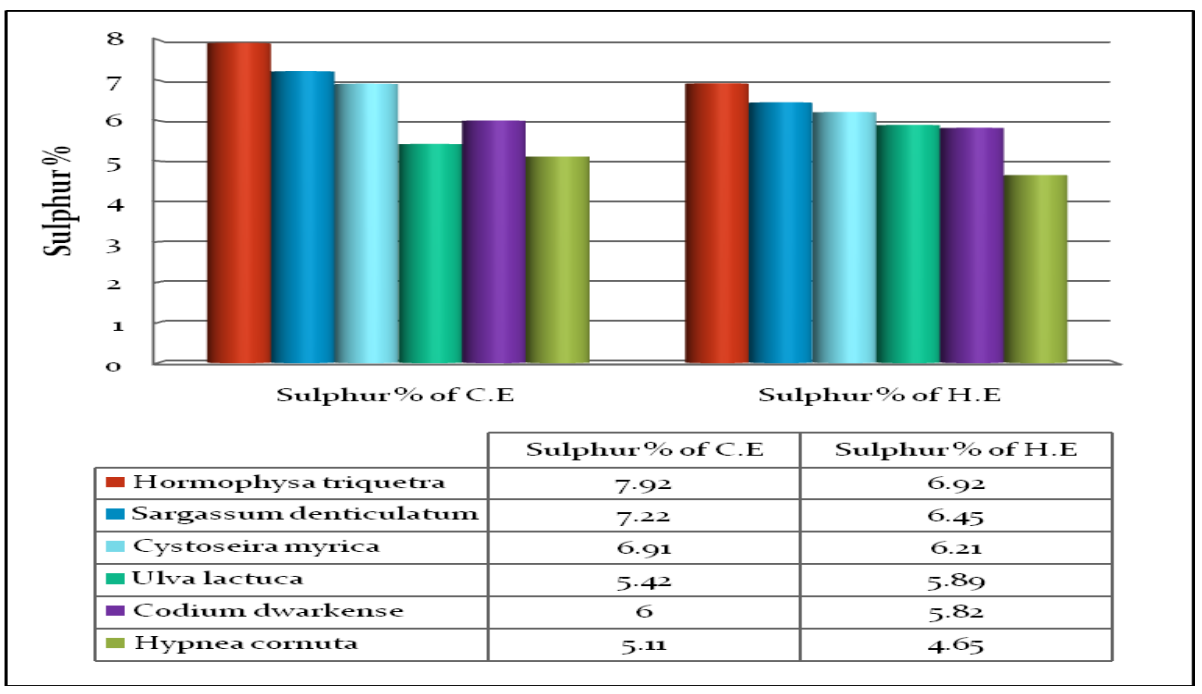

Fig .9: Variations in sulphur content (\%) in the SPs cold and hot extracts for different marine algal species . 


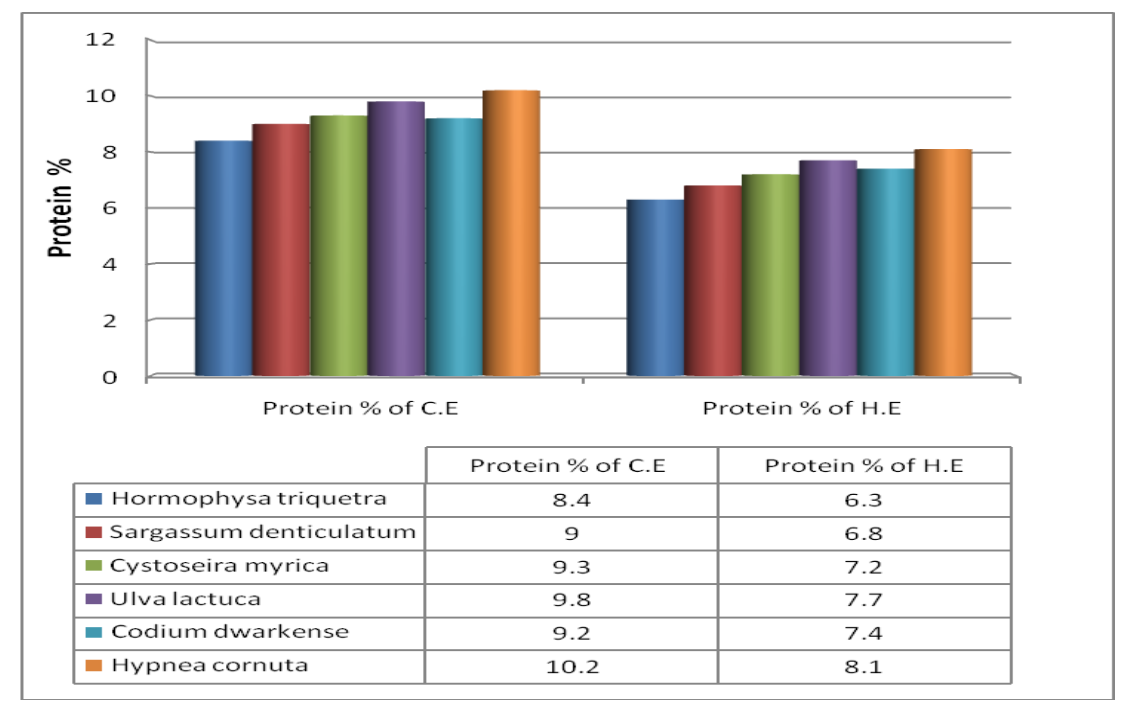

Fig .10: Variations in protein content $(\%)$ in the SPs cold and hot extracts for different marine

- Uronic acid \% (Fig. 11) algal species .

The uronic acid concentrations of the SPs cold and hot extracts. In cold extracts the maximum concentration value was 3.2\% in Hypnea cornuta, while the minimum concentration value was $\mathbf{1 . 8 \%}$ in Hormophysa triquetra. On the other hand the maximum concentration value in hot extracts was $\mathbf{2 . 8 \%}$ in Hypnea cornuta and the minimum concentration value was $\mathbf{1 . 5} \%$ in Hormophysa triquetra .

\section{- Nitrogen content \% (Fig. 12 )}

The nitrogen concentrations of the SPs cold and hot extracts. In cold extracts the maximum concentration value was $\mathbf{3 . 8 8} \%$ in Hypnea cornuta, while the minimum concentration value was $\mathbf{2 . 9 4} \%$ in Hormophysa triquetra. On the other hand the maximum concentration value in hot extracts was $\mathbf{2 . 7 1 \%}$ in Hypnea cornuta and the minimum concentration value was $\mathbf{1 . 3 8 \%}$ in Hormophysa triquetra

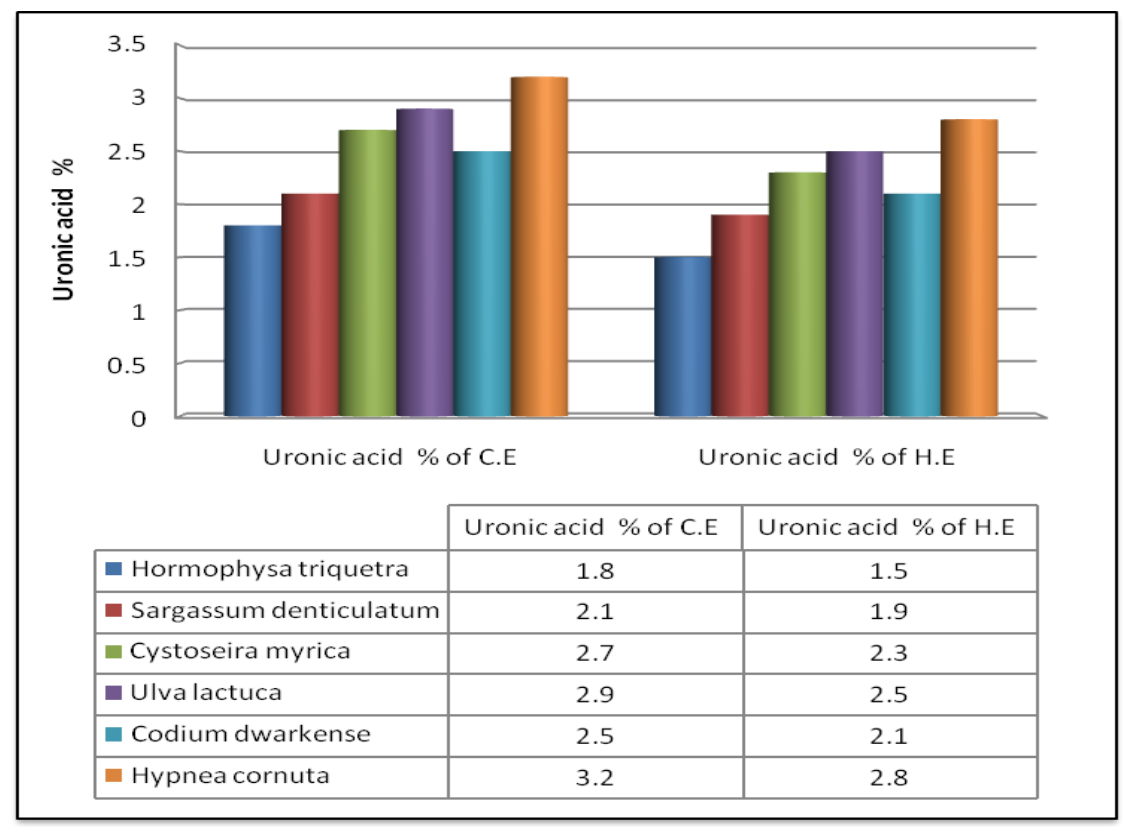

Fig .11: Variations in uronic acid content (\%) in the SPs cold and hot extracts for six marine algal species . 


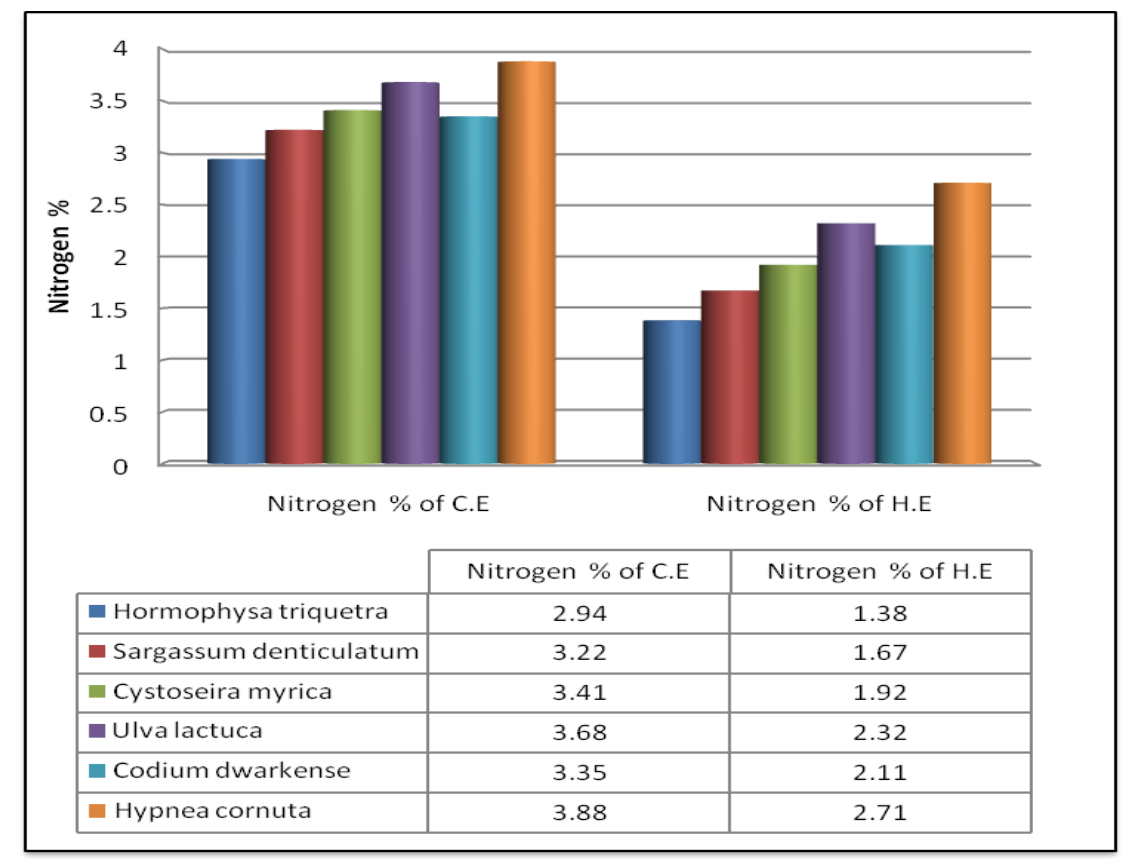

Fig .12: Variations in nitrogen content $(\%)$ in the SPs cold and hot extracts for different marine algal species .

Blood anticoagulation activity of the sulphated polysaccharides by using different conc. (20,10 and 5\%) from cold and hot SPs extracts :

\section{1) The prothrombin time ( PT) test (Table 1)}

The significant highest value of prothrombin time was $\mathbf{2 6 . 5 0 \pm 0 . 1 0}$ sec at conc. $20 \%$ SPs cold extract of the brown alga Hormophysa triquetra, while the significant lowest value was $\mathbf{1 . 1 3} \pm \mathbf{0 . 0 6} \mathrm{sec}$ at conc $5 \%$ SPs hot extract of the red alga Hypnea cornuta .

\section{2) The prothrombin activity (Table 2 )}

The significant highest value of prothrombin activity was $\mathbf{1 4 2 9 . 0}$ at conc.5\% SPs hot extract of the red alga Hypnea cornuta, while the significant lowest value was 47.63 $\pm \mathbf{0 . 3 5}$ at conc. $20 \%$ SPs cold extract of the brown alga Hormophysa triquetra.

\section{3) International normalization ratio (Table 3)}

The significant highest value of the international_normalization was $\mathbf{2 . 1 1} \pm \mathbf{0 . 0 1}$ at conc. 20\% SPs cold extract of the brown alga Hormophysa triquetra, while the lowest value was $\mathbf{0 . 0 8} \pm \mathbf{0 . 0 2}$ at conc. 5\% SPs hot extract of the red alga Hypnea cornuta .

\section{4) Activated partial thromboplastin time (APTT) test (Table 4)}

The significant highest value of activated partial thromboplastin time (42.20 $\pm 0.10 \mathrm{sec})$ was recorded at conc. $20 \%$ SPs cold extract of the brown alga Hormophysa triquetra, On the other hand, the lowest value $\mathbf{( 5 . 6 3 \pm 0 . 2 5} \mathrm{sec})$ was at conc. 5\% SPs hot extract in the red alga Hypnea cornuta . 
Table 1: Effect of different concentrations (20,10 and $5 \%)$ from cold and hot SPs extracts for six marine algal species on prothrombin time(sec) (Mean \pm SD)

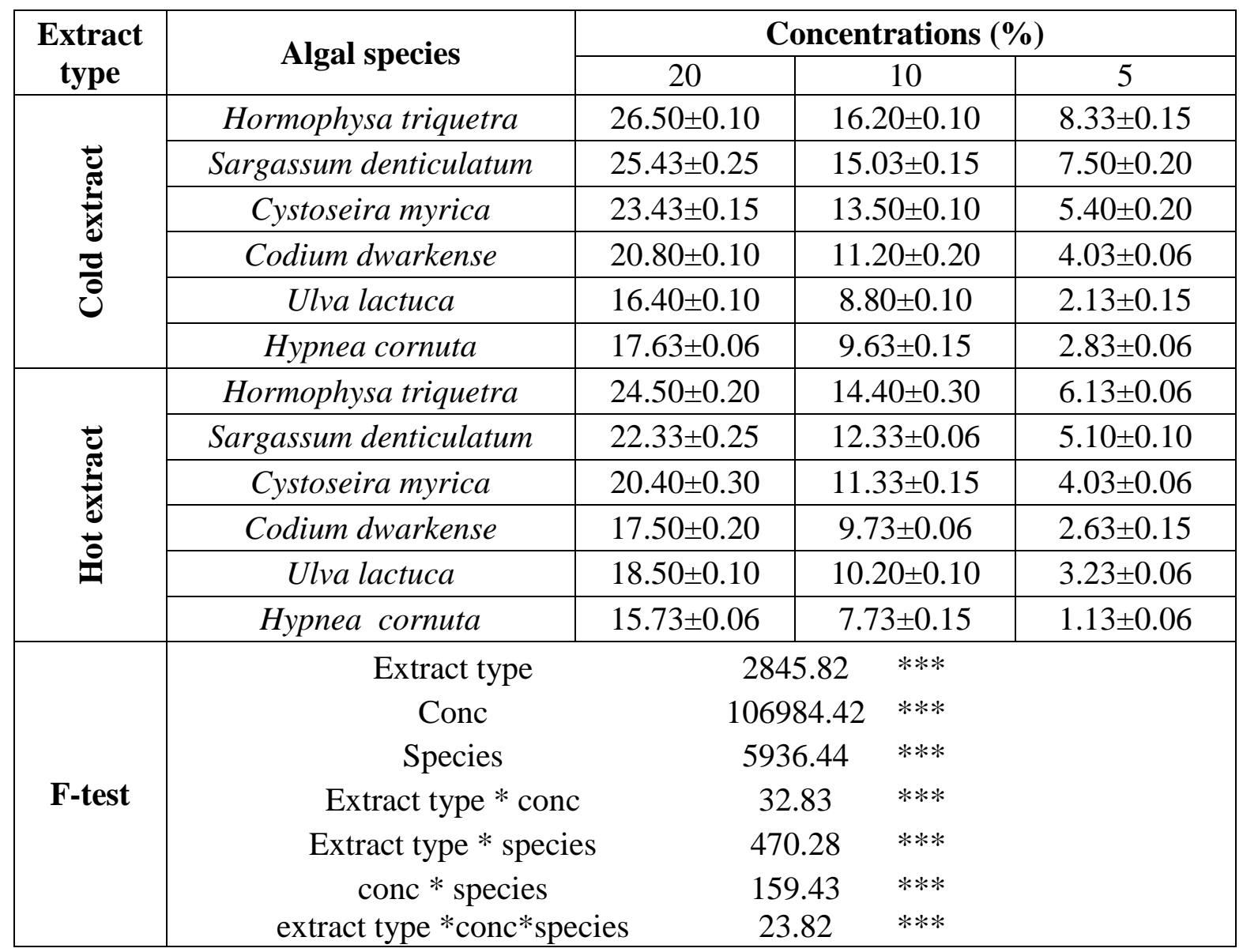

The statistical analysis shows that there was significance difference between the two methods of extrations (cold and hot); the three concentrations; the studied species and the interaction between the investigated variables at $P<0.001$. 
Table 2: Effect of different concentrations (20,10 and $5 \%)$ from cold and hot SPs extracts for six marine algal species on prothrombin activity (\%) (Mean \pm SD)

\begin{tabular}{|c|c|c|c|c|}
\hline \multirow{2}{*}{$\begin{array}{c}\text { Extract } \\
\text { type }\end{array}$} & \multirow{2}{*}{ Algal species } & \multicolumn{3}{|c|}{ Concentrations (\%) } \\
\hline & & 20 & 10 & 5 \\
\hline \multirow{6}{*}{ 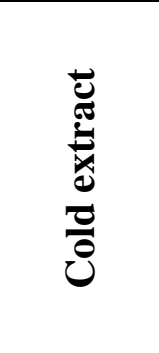 } & Hormophysa triquetra & $47.63 \pm 0.35$ & $79.33 \pm 0.58$ & $160.00 \pm 3.61$ \\
\hline & Sargassum denticulatum & $49.50 \pm 0.50$ & $86.00 \pm 1.00$ & $179.33 \pm 5.13$ \\
\hline & Cystoseira myrica & $53.90 \pm 0.46$ & $95.67 \pm 1.53$ & $254.00 \pm 10.15$ \\
\hline & Codium dwarkense & $61.30 \pm 0.40$ & $117.33 \pm 2.52$ & $340.33 \pm 6.35$ \\
\hline & Ulva lactuca & $78.70 \pm 0.60$ & $151.67 \pm 2.52$ & $668.33 \pm 44.55$ \\
\hline & Hypnea cornuta & $72.57 \pm 0.58$ & $138.33 \pm 3.06$ & $509.33 \pm 28.87$ \\
\hline \multirow{6}{*}{ 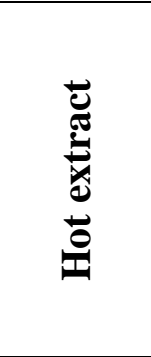 } & Hormophysa triquetra & $51.80 \pm 0.30$ & $90.00 \pm 2.00$ & $220.33 \pm 2.89$ \\
\hline & Sargassum denticulatum & $56.57 \pm 0.97$ & $106.33 \pm 1.15$ & $270.00 \pm 7.00$ \\
\hline & Cystoseira myrica & $62.47 \pm 0.75$ & $115.67 \pm 1.53$ & $340.33 \pm 6.35$ \\
\hline & Codium dwarkense & $73.50 \pm 1.10$ & $135.67 \pm 0.58$ & $547.67 \pm 44.46$ \\
\hline & Ulva lactuca & $69.23 \pm 0.29$ & $129.33 \pm 1.53$ & $428.67 \pm 10.97$ \\
\hline & Hypnea cornuta & $82.13 \pm 0.40$ & $174.00 \pm 4.58$ & $1429.00 \pm 0.00$ \\
\hline \multirow{7}{*}{ F-test } & \multicolumn{3}{|c|}{$852.7756 \quad * * *$} & \\
\hline & Conc & \multicolumn{2}{|c|}{10112.64} & \\
\hline & species & 1370.54 & $* * *$ & \\
\hline & Extract type $*$ conc & 624.8703 & $* * *$ & \\
\hline & Extract type $*$ species & 535.7639 & $* * *$ & \\
\hline & conc $*$ species & 905.146 & $* * *$ & \\
\hline & Extract type $*$ conc* species & 432.6893 & $* * *$ & \\
\hline
\end{tabular}

The statistical analysis illustrates that there was significance variation between the two procedures of extractions (cold and hot); the three concentrations; the studied species and the interaction between the investigated variables at $P<0.001$ 
Table 4: Effect of different concentrations (20,10 and $5 \%)$ from cold and hot SPs extracts for six marine algal species on activated partial thromboplastin time(sec) $($ Mean \pm SD)

\begin{tabular}{|c|c|c|c|c|}
\hline \multirow{2}{*}{$\begin{array}{c}\text { Extract } \\
\text { type }\end{array}$} & \multirow{2}{*}{ Algal species } & \multicolumn{3}{|c|}{ Concentrations $(\%)$} \\
\hline & & 20 & 10 & 5 \\
\hline \multirow{6}{*}{ 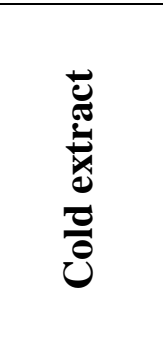 } & Hormophysa triquetra & $42.20 \pm 0.10$ & $33.30 \pm 0.10$ & $22.80 \pm 0.20$ \\
\hline & Sargassum denticulatum & $41.53 \pm 0.15$ & $32.10 \pm 0.10$ & $21.03 \pm 0.15$ \\
\hline & Cystoseira myrica & $39.70 \pm 0.10$ & $30.43 \pm 0.06$ & $17.50 \pm 0.20$ \\
\hline & Codium dwarkense & $37.53 \pm 0.25$ & $28.43 \pm 0.15$ & $14.73 \pm 0.06$ \\
\hline & Ulva lactuca & $33.80 \pm 0.10$ & $23.40 \pm 0.10$ & $8.10 \pm 0.10$ \\
\hline & Hypnea cornuta & $34.23 \pm 0.06$ & $26.10 \pm 0.10$ & $8.63 \pm 0.15$ \\
\hline \multirow{6}{*}{ 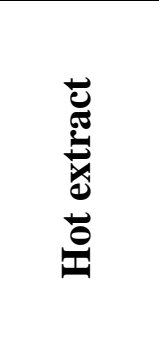 } & Hormophysa triquetra & $40.43 \pm 0.15$ & $31.80 \pm 0.20$ & $19.20 \pm 0.10$ \\
\hline & Sargassum denticulatum & $38.23 \pm 0.15$ & $29.73 \pm 0.15$ & $17.00 \pm 0.10$ \\
\hline & Cystoseira myrica & $37.70 \pm 0.20$ & $28.60 \pm 0.10$ & $14.73 \pm 0.06$ \\
\hline & Codium dwarkense & $34.10 \pm 0.10$ & $26.17 \pm 0.12$ & $8.43 \pm 0.06$ \\
\hline & Ulva lactuca & $35.40 \pm 0.20$ & $27.30 \pm 0.20$ & $10.93 \pm 0.06$ \\
\hline & Hypnea cornuta & $32.43 \pm 0.06$ & $21.20 \pm 0.10$ & $5.63 \pm 0.25$ \\
\hline \multirow{7}{*}{ F-test } & \multicolumn{2}{|c|}{ Extract type } & 5747.445 & $* * *$ \\
\hline & \multicolumn{2}{|c|}{ Conc } & 254639 & $* * *$ \\
\hline & \multicolumn{2}{|c|}{ Species } & 15011.87 & $* * *$ \\
\hline & \multicolumn{2}{|c|}{ Extract type $*$ conc } & 222.7225 & $* * *$ \\
\hline & \multicolumn{2}{|c|}{ Extract type $*$ species } & 1394.637 & $* * *$ \\
\hline & \multicolumn{2}{|c|}{ Conc $*$ species } & 535.9263 & $* * *$ \\
\hline & \multicolumn{2}{|c|}{ Extract type $*$ conc $*$ species } & 115.5722 & $* * *$ \\
\hline
\end{tabular}

The statistical analysis shows that there was significance difference between the two methods of extrations (cold and hot); the three concentrations; the studied species and the interaction between the investigated variables at $P<0.001$

\subsection{Discussion:}

The present results of chlorophyll (a) concentrations (Fig. 1) were in agreement with that of Kumar et al.(2009) who mentioned that the highest chlorophyll (a) content was observed in the green alga Cladophora fascicularis followed by the green alga Caulerpa seertulariodes while the lowest chlorophyll $a$ content was recorded in the red alga Champia compressa. Also, The results of the current study corroborated with the findings of Francisco et al. (2006) stating highest chlorophyll (a) content in green algae and lowest in red algae.

The current results of chlorophyll (b) concentrations (Fig. 2) were in agreement with that of Kumar et al.(2009) who observed that the richest in chlorophyll (b) content was the green alga Cladophora fascicularis, While the lowest chlorophyll (b) content was noted in the brown alga Sargassum polycustum. Similar observations were incurred by Chakraborty and Santra (2008). 
The present results of chlorophyll (c) concentrations (Fig. 3 )were in agreement with that of Seely et al.(1972) who reported that the brown algae of intertidal and subtidal zones of the shorelines are abundant source for chlorophyll (c).

The current results of carotenoids concentrations (Fig. 4) were corroborated with the findings of Kumar et al.(2009) who observed that the highest carotenoids were reported in Sargassum polycustum followed by Padina gymnospora both belonging to the Phaeophyta group. Also, Fritsch (1971) stated that there is high carotene content in brown algae .

The present results of the yield SPs cold and hot extracts (Fig. 5) were higher than found by Shanmugam et al.(2001) who reported that the yield ranged from 1.8 4.0\% because they used only green algae species. The present results for codium $d$ warkense in agreement with that of Shanmugam et al.(2002) who reported that the yields of cold water extract and hot water extract were $4.40 \%$ and $\mathbf{4 . 6 0} \%$ respectively. Also, Siddhanta et al.(1999) recorded that the yields of CWE and HWE were $4.4 \%$ and $\mathbf{4 . 6 \%}$ respectively for the green marine alga Codium dwarkense.

The current results of $\mathrm{pH}$ for of the yield SPs cold and hot extracts (Fig. 6 )were in agreement with that of Shanmugam et al.(2001) who recorded that all SPs products were slightly alkaline in nature $(\mathrm{pH}$ 7.1- 8.4).

The present results of the total sugar for SPs cold and hot extracts (Fig.7) in agreement with that of Siddhanta et al.(1999) who reported that the total sugar contents in cold water extract were higher than hot water extract of Codium dwarkense . Also, Shanmugam et al.(2001) mentioned that the total sugar content in both cold and hot water extracts of some Indian marine green algae was $>\mathbf{2 0} \%$. Furthermore, Shanmugam et al.(2002) recorded that the total sugar content was higher in all cold water SPs extracts of Codium species than in the hot water ones. Also, Manoj et al.(2013) mentioned that sugar content in SPs extracts of the brown algae Turbinaria ornata and Padina tetrastromatica were 56.42 and $50 \%$ respectively.

The total sulphate content in all cold and hot water SPs extracts( Fig. 8) were in agreement with that of Siddhanta et al.(1999) who mentioned that the total sulphate content was higher in cold water extracts of Codium dwarkense species than in the hot water ones. Also, Manoj et al.(2013) corroborated the current results when recorded that Sargassum wightii and Sargassum tenerrimum showed high content of sulphate in SPs extracts.

Furthermore, Wang et al.(2007) reported that Sulphate content in SPs extracts from red algae Grateloupia longifolia and Grateloupia filicin were $\mathbf{1 8 . 5}$ and $\mathbf{2 5 . 7} \%$ respectively. Also, Siddhanta et al.(1999) mentioned that sulphate were $\mathbf{2 6 . 5 0} \%$ and $19.50 \%$ in SPs cold and hot extracts respectively. But these results were higher than that of Vijayabaskar et al .(2012) who recorded that sulphate content in SPs extract from the brown marine algae Sargassum swartzii was $\mathbf{5 . 3} \%$.

The present results of the sulfur content for SPs cold and hot extracts (Fig. 9) were in agreement with Shanmugam et al.(2001) who recorded that the sulphur content in cold and hot SPs extracts of some Indian marine green algae ranged between 2.61-6.18\%. But these results were higher than that obtained by Vijayabaskar et al .(2012) who recorded that sulphur content in SPs extract from the brown marine algae Sargassum swartzii was $\mathbf{0 . 9 8 \%}$. 
The current results of the protein content for SPs cold and hot extracts ( Fig. 10) were in agreement with that of Shanmugam et al.(2001) who mentioned that species of Ulva and Caulerpa contained 7.0-10 \% protein in cold and hot SPs extracts. Moreover, Siddhanta et al.(1999) corroborated the current results when recorded that protein content in cold extract SPs of Codium dwarkense was $\mathbf{1 0 . 1 0 \% .}$ Also, Shanmugam et al.(2002) revealed that protein contents of cold water SPs extracts of all Codium spp. were higher than hot water ones.

The present results of uronic acid content for SPs cold and hot extracts (Fig. 11) were in agreement with that of Shanmugam et al.(2001) who mentioned that trace of uronic acid was found in SPs extracts of some Indian marine green algae ranged between 2-4\%. Also, Shanmugam et al.(2002) recorded that uronic acid content in Codium spp. ranged from 1.5 to 3.0 \% . These results were lower than that found by Karnjanapratum and You (2011) who recorded that uronic acid content in the crude SPs of Monostroma nitidum was $\mathbf{1 8 . 6} \%$ and also lower than that found by Mao et al.(2006) who reported that uronic acid contents in the sulfated polysaccharides extracted from Ulva conglobata ranged between 10.82-14.91\% this may be because they used different species of marine algae .

The current results of nitrogen content in SPs cold and hot extracts (Fig. 12) in agreement with that of Shanmugam et al.(2001) who reported that the concentration of nitrogen in cold and hot SPs extracts of some some Indian marine green algae ranged between 1.55- 4.25\%. But these results were higher than that found by Vijayabaskar et al (2012) who recorded that nitrogen content in SPs extract from the brown marine algae Sargassum swartzii was $\mathbf{0 . 1 5} \%$.

The present results (Table 1) in agreement with that of Ferna'ndez et al. (2012) who studied the anticoagulation efficacy of sulfated $\beta$-D-mannan extracted from green seaweed Codium vermilara and reported that higher sulfate content leads to more pronounced effect. As well, Mulloy et al.(2000) who reported that the high anticoagulant activity of algal fucans appears to correlate with the presence of sulphated fucose branches.

Qiu et al. (2006) reported that the anticoagulation activity improve with increase in sulphate content of the native fucoidan. Also, Shanmugam et al. (2002) corroborated the present results when reported that cold water SPs extract of Codium tomentosum, Codium dwarkense and Codium tenue containing comparatively lower uronic acid and higher sulphate showed stronger blood anticoagulant activity. As well, cold water SPs extracts of some of the species like Codium geppei and Codium coronatum containing less sulphate and more uronic acid showed relatively poor blood anticoagulant activity and that's what happened Ulva lactuta in the present study when the hot SPs extracts showed higher blood anticoagulant activity than the cold ones because they contain higher sulphate and sugar content.

Furthermore, Uehara et al .(1992) have reported that cold water extract from Codium latum of Japanese waters exhibited potent blood anticoagulant activity, whereas from the green alga Monostroma nitidum active fraction was obtained only by hot water extraction. This seems to be due to the difference in sugar and sulphate contents of the SPS. Similar finding was also reported by Nishino and Nagumo (1992) while working on Ecklonia kurome. Moreover, It was observed that the anticoagulant activity of Codium dwarkense is proportional to the carbohydrate and 
sulphate contents and inversely proportional to the protein and uronic acid contents (Siddhanta et al.,1999).

The present results (Table 2) in agreement with that of Croci et al. (2011) who studied that the SPs from the brown seaweed Laminaria saccharina shows promising activity on thrombosis. Also, It was observed that anticoagulant activity was higher in SP samples with higher sulfate content. In this regard, Codium vermilara proved to be superior with a higher degree of sulfation and arabinose content (Ciancia et al., 2007).

The current results (Table 3) in agreement with that of (Shanmugam et al., 2002) who concluded that higher blood anticoagulant activity is associated with relatively higher contents of sugar and sulphate and lower protein and uronic acid contents. Also, Cumashi et al.(2007) reported that fucans from 10 brown seaweeds each prolonged the clotting time of human plasma; however, only five of these fucans had significant activity against thrombin induced platelet aggregation .

The present results( Table 4) in agreement with that of Athukorala et al.( 2007) who mentioned that APTT activity of crude polysaccharide fraction increased with the sample concentration. Also, The high APTT values indicated that the crude SPs from Sargassum tenerrimum have high anticoagulation activity followed by Sargassum wightii $>$ Turbinaria ornata $>$ Turbinaria conoides $>$ Padina tetrastromatica (manoj et al.,2013) .

Also, The hot water extract of green alga Monostroma latissimum gives a sulfated rhamnan polysaccharide with an anticoagulant activity. The anticoagulant activity as evaluated by assays of the APTT promises that it can be a potential source of anticoagulant (Li et al. 2011).

Furthermore, Chevolot et al.(1999) concluded that marine brown algae extracts exhibit higher anticoagulant activity than red and green algae extracts .

\section{Conclusion:}

Egyptian marine algae are still inexhaustible especially in the extraction of valuable medical materials. The results revealed that SPs extracts from brown algae exhibit higher anticoagulation activity than green and red algae. As well as, the anticoagulation activity is proportional to sulphate and sugar contents in SPs extracts and inversely proportional to protein and uronic acid content .

\section{References :}

Albuquerque, I.R.L; Queiroz, K.C.S; Alves, L.G; Santos, E.A; Leite, E.L and Rocha, H.A.O Heterofucans from Dictyota menstrualis have anticoagulant activity. Braz. J. Med. Biol. 37,167-171 (2004)

American Public Health Association (APHA). Standard methods for examination of water and wastewater.19 $\left.{ }^{\text {th }}\right)$. (1995)

American Standard Test Methods (ASTM) American Society for testing and materials. ASTM International, United States. (2002)

Athukorala ,Y. ; Lee, K.W. ; Kim ,S.K and Jeon, Y.J. Anticoagulant activity of marine green and brown algae collected from Jeju Island in Korea. Bioresource technology, 98(9), pp.1711-1716. (2007) 
Chakraborty, S. and Santra, S.C. Biochemical composition of eight benthic algae collected from Sunderban. Indian J. of Marine Sciences. 37(3),329-332. (2008)

Chevolot, L.; Foucault, A.; Chaubet, F.; Kervarec, N.; Sinquin, C. and Fisher, A. M. Further data on the structure of brown seaweed fucans: Relationships with anticoagulant activity. Carbohydrate Research, 319, 154-165 . (1999)

Ciancia,M.; Quintana, I.; Vizcargu'naga, M.I.; Kasulin, L.; de Dios, A.; Estevez, J.M. and Cerezo, A.S. Polysaccharides from the green seaweeds Codium fragile and Codium vermilara with controversial effects on hemostasis. Int J Biol Macromol .41,641-649 (2007)

Costa, L.S.; Telles, C.B.; Oliveira, R.M.; Nobre, L.T.; Dantas-Santos, N.; Camara, R.B.; Costa, M.S.; Almeida-Lima, J.; Melo-Silveira, R.F.; Albuquerque, I.R.; Leite, E.L. and Rocha, H.A. Heterofucan from Sargassum filipendula induces apoptosis in HeLa cells. Mar Drugs. 9, 603-614 (2011)

Croci, D.O.; Cumashi, A.; Ushakova, N.A.; Preobrazhenskaya, M.E.; Piccoli, A.; Totani, L.; Ustyuzhanina, Ne.; Bilan ,M.I.; USov, A.I.; Grachev ,A.A.; Morozevich, G.E.; Berman, A.E.; Sanderson, C.J.; Kelly. M.; DiGreg- orio, P.; Rossi, C.; Tinari, N.; Iacobelli, S.; Rabinovich, G.A.; Nifantiev,N.E. Fucans, but not fucomannoglucuronans, determine the biological activities of sulfated polysaccharides from Laminaria saccharina brown seaweed. PLoS One 28:e17283. doi: 10.1371/journal.pone.0017283 (2011)

Cumashi, A.; Ushakova, N.A.; Preobrazhenskaya, M.E.; D'Incecco, A.; Piccoli, A.; Totani, I. and Tinari, N. A. Comparative study of anti-inflammatory, anticoagulant, anti-angiogenic, and antiadhesive activities of nine different fucoidans from brown seaweeds. Glycobiology, 17, 541-552 (2007)

Dodgson, K.S. and Price, R.G. A note on the determination of ester sulphate content of sulphated polysaccharides,Biochem.J.84 ,106-481. (1962)

Duarate, M.; Cardoso, M. and Noseda, M. Structural studies on fucoidans from the brown seaweed Sargassum stenophyllum. Carbohydrate .333,281-293 (2001)

Dubois, M.; Gilles,K.A.; Hamilton, J.K; Repers, P.A and Smith,FColormetric method for determination of sugars and related substances, Analyt.Chem. 18,350-356 (1956)

Ferna'ndez, P.V.; Estevez, J.M.; Cerezo, As. and Ciancia, M. Sulfated b-Dmannan from green seaweed Codium vermilara.CarbohydrPolym.87,916-919 (2012)

Francisco, J.L.G.; Aguilera, J. and Jimenez, C. The response of nutrient assimilation and biochemical composition of Arctic sea-weeds to anutrient input in summer. J. Exp. Botany. Doi:10.1093/jxb/er1029 (2006)

Fritsch, F.E. The structure and reproduction of the algae, Vol I, Cambridge Univ. Press,Cambridge. 791 p ( 1971) 
Hayakawa, Y.; Hayashi, T.; Lee, J. B.; Srisomporn, P.,;Maeda, M. and Ozawa, T. Inhibition of thrombin by sulfated polysaccharides isolated from green algae. Biochimica Biophysica Acta. 1543, 86-94 (2000)

Jung, W.K.; Je, J.Y. and Kim, S.K. A novel anticoagulant protein from Scapharca broughtonii. Journal of Biochemistry and Molecular Biology. 35, 199-205. (2001)

Karnjanapratum, S. and You, S. Molecular characteristics of sulfated polysaccharides from Monostroma nitidum and their in vitro anticancer and immunomodulatory activities, International Journal of Biological Macromolecules ,48, 311-318(2011)

Knutson, C. A and Jeans, A. A new modification of the carbazole analysis. Application to heteropolysaccharides, Anal Biochem, 24: 470-481 (1968)

Kumar, N.J.I.; Kumar, R.N. ; Bora, A. ; Kaur Amb, M. and Chakraborthy, S. An Evaluation of the Pigment Composition of Eighteen Marine Macroalgae Collected from Okha Coast, Gulf of Kutch, India. Our nature.7, 48-55. (2009)

Lahaye, M. and Ray, B. Cell-wall polysaccharides from the marine green alga Ulva rigida (Ulvales,Chlorophyta)-NMR analysis of ulvan oligosaccharides. Carbohydr. Res .283, 161-173. (1996)

Li ,H.; Mao, W.; Zhang, X.; Qi, X.; Chen, Y.; Chen, Y.; Xu, J.; Zhao, C.; Hou, Y.; Yang, Y.; Li, N. and Wang, C. Structural characterization of an anticoagulant-active sulfated polysaccharide isolated from green alga Monostroma latissimum. Carbohydr Polym. 85,394-400. (2011)

Lowry ,O.M .; Rosebrough ,N.J. ;Farr ,L.A. and Randall,R.J. Protein measurements with folin phenol reagent, J.Biol .Chem.193,265-275. (1951)

Manoj , S.G.M.; Mahesh ,K.P. S.; Vasanthi, M. and Anant ,A. Anticoagulant property of sulphated polysaccharides extracted from marine brown algae collected from Mandapam Island, India.African Journal of Biotechnology. 12(16), pp.1937-1945. (2013)

Mao, W.; Zang, X.; Li, Y. and Zhang, H. Sulfated polysaccharides from marine green algae Ulva conglobata and their anticoagulant activity. J. Appl. Phycol .18, 9-14 (2006)

Mao, W.J; Fang, F.; Li, H.Y; Qi, X.H; Sun, H.H; Chen, Y. and Guo, S.D Heparinoid-active two sulfated polysaccharides isolated from marine green algae Monostroma nitidum. Carbohydr Polym .74,834-839. (2008)

Mulloy, B. ; Mourão, P.A.S. and Gray, E. Structure/function studies of anticoagulant sulphated polysaccharides using NMR. Journal of Biotechnology, 77(1), pp.123-135 (2000)

Ngo, D.H. and Kim, S.K. Sulfated polysaccharides as bioactive agents from marine algae. International Journal of Biological Macromolecules.62, pp.70-75 (2013) 
Nishino,T. and Nagumo, T. Anticoagulant and antithrombin activities of oversulfated fucans. Carbohydr. Res. 229,355-362 (1992)

Papenfuss,G.F. (1968): A history, catalogue and bibliography of Red Sea benthic algae. Israel Journal of Botany.17,1-2.

Patel, $\mathbf{S}$ Therapeutic importance of sulfated polysaccharides from seaweeds: updating the recent findings. 3 Biotech. 2, pp.171-185 ( 2012)

Pereira, M. S.; Melo, F. R. and Mourao, P. A. S. Is there a correlation between structure and anticoagulant action of sulfated galactans and sulfated fucans? Glycobiology. 12, 573-580 (2002)

Pushpamali, W.A.; Nikapitiya, C.; De Zoysa, M.; Whang, I.; Kim, S.J.and Lee, J. Isolation and purification of an anticoagulant from fermented red seaweed Lomentaria catenata. Carbohydr Polym .73,274-279 (2008)

Qiu, X.D.; Amarasekara, A. and Doctor, V. Effect of oversulfation on the chemical and biological properties of fucoidan. Carbohydr. Polym. 63,224-228 (2006)

Raja, A.; Vipin, C. and Aiyappan, A. Review Article Biological importance of Marine Algae- An overview. 2(5), pp.222-227 ( 2013)

Seely, G.R.; Duncan, M.G. and Vidaver ,W.E. Preparative and analytical extraction of pigments of brown algae with dimethyl sulfoxide .Marine biology .12,184188 (1972)

Shanmugam, M.; Mody, K. H. ; Ramavat, B. K. ; Sai Krishna Murthy, A. and Siddhanta, A.K. Screening of Codiacean algae (Chlorophyta) of the Indian coasts for blood anticoagulant activity. Indian Journal of Marine Sciences. 31(1), pp.33-38 (2002)

Shanmugam, M.; Ramavat, B. K. ; Mody, K. H.; Oza, R. M., and Tewari, A. Distribution of heparinoid-active sulphated polysaccharides in some Indian marine green algae. Indian Journal of Marine Sciences. 30(4), 222-227 (2001)

Siddhanta, A.K.; Shanmugam ,M.; Mody, K.H.; Goswami, A.M. and Ramavat, B.K. Sulphated polysaccharides of Codium dwarkense Boergs. from the west coast of India: Chemical composition and blood anticoagulant activity. International Journal of Biological Macromolecules. 26(2-3), pp.151-154 (1999)

Silva ,T.M.A; Alves, L.G; Queiroz, K.C.S; Santos, M.G.L; Marques, C.T; Chavante, S.F ;Rocha, H.A.O and Leite, E.L. Partial characterization and anticoagulant activity of a heterofucan from the brown seaweed Padina gymnospora. Braz. J. Med. Biol. Res. 38,523-533 (2005)

Strickland, J. D. H. and Parsons, T. R. A practical handbook of sea water analysis. Fish. Res., Bd. Ca.167 ,311 pp (1968) 
Subash, A .; Hanumantha, R.B.R. and Adoor GS . In vitro antioxidant and in vivo anti inflammatory potential of crude polysaccharide from tubinaria ornate (Marine Brown Alga), food ChemToxicol .48(1),187-192. ( 2010)

Timothy, R.P. ; Yoshiaki Maita and Carol, M.Lalli Amanual of chemical and biological methods for sea water Analysis. (2013)

Uehara,T.; Takeshita, M. and Maeda, M. Studies on anticoagulant-active arabinan sulfates from the green alga Codium latum, Carbohydr Res. 235 , 309- 311. (1992)

Vijayabaskar, P.; Vaseela, N. and Thirumaran, G. Potential antibacterial and antioxidant properties of a sulfated polysaccharide from the brown marine algae Sargassum swartzii. Chinese Journal of Natural Medicines. 10(6), pp.421-428. (2012)

Wang, S.C.; Blighb, S.W.A.; Shia, S.S.; Wanga, Z.T.; Hua, Z.B.; Crowder, J. and Branford-Whiteb, C. Structural features and anti-HIV-1 activity of novel polysaccharides from red algae Grateloupia longifolia and Grateloupia filicina. International Journal of Biological Macromolecules,41(4), pp.369375. (2007) 


\section{الملخص باللغة العربية}

استخلاص عديدات التسكر الكبريتية من انواع مختلفة من الطحالب البحرية ودراسة دورها كمضادات تجلط

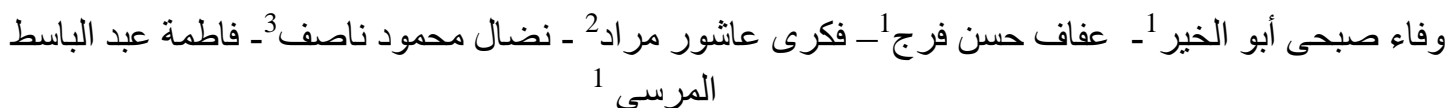

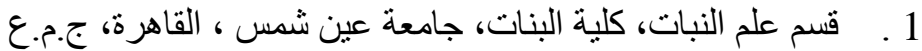

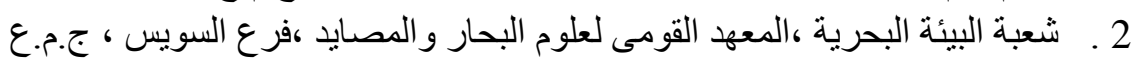

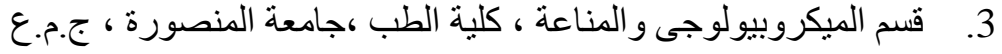

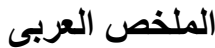

الطحالب البحرية تعتبر أهم مصدر غير حيو انى لعديدات التسكر الكبريتية التى لديها الكثير من الفو ائد فى مجال

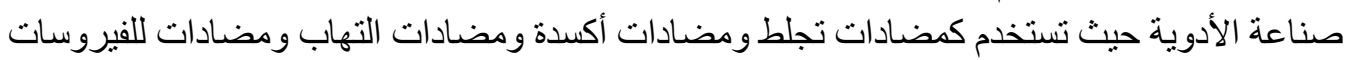

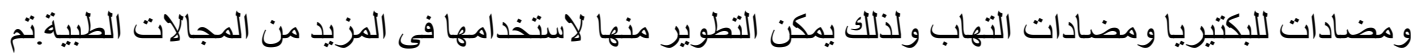

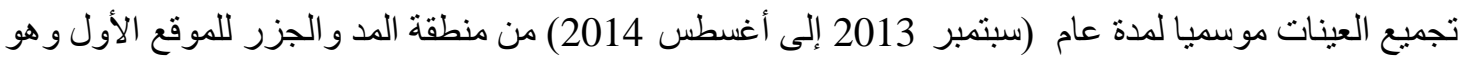

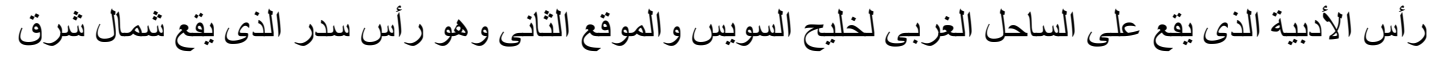

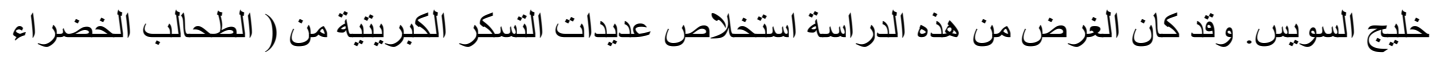
ومن الطحالب الحمراء Codium dwarkense , Ulva Lactuca البنية Sargassum denticulatum، Hormophysa triquetra و و Cystosira myrica ) بطريقتين مختلفتين ( على الساخن و البارد ) وتم التحليل الكيميائي لكل مستخلص (محتوى البروتين، السكريات،

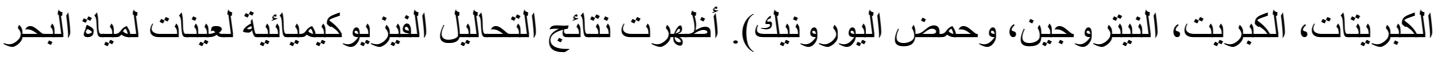

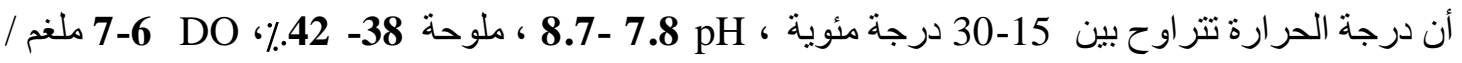

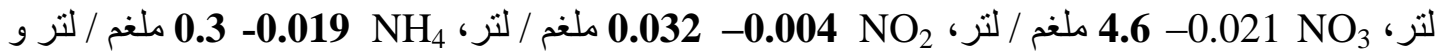

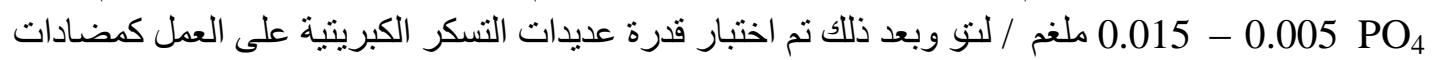

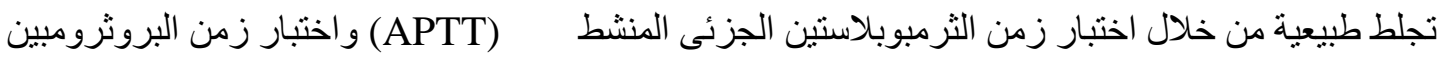

(PT)

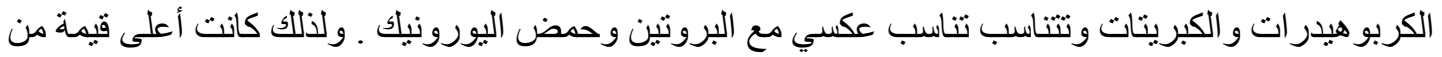

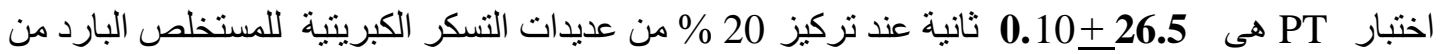

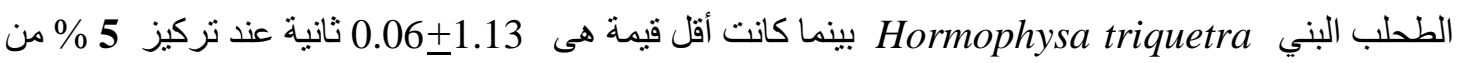

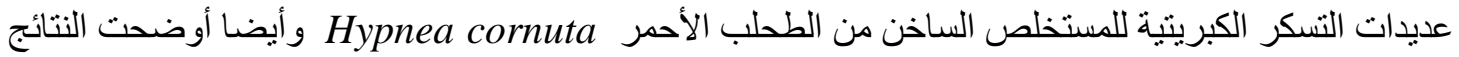

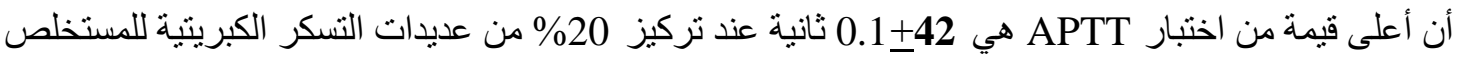
البارد من الطحلب البني مormophysa triquetra وكانت أقل قيمة هى

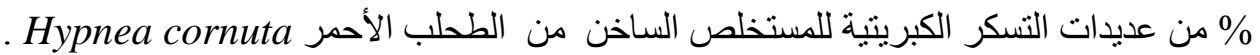

